\title{
Pengaruh suplementasi seng dan vitamin b6 terhadap kadar hemoglobin, hematokrit dan indeks eritrosit pasien malaria vivax yang anemia
}

\author{
Sofiyetti $^{1}$, Edi Dharmana², M. Zen Rahfiludin ${ }^{3}$, Nyoman Suci W' ${ }^{4}$, Diana Nur Afifah ${ }^{5}$
}

\begin{abstract}
Background: Zinc supplementation decrease the risk of malaria parasitaemia, increasing ferritin serum level and hemoglobin in patients with malaria. Zinc influence the activity of aminolevulinic acid dehydratase (ALAD) an enzymes that catalizes heme synthesize. Vitamin B6 in pyridoxal 5-phosphate (PLP) from has a role in alpha-aminolevulinic acid (ALA) formation, which is the precursor of heme in hemoglobin. PLP also inhibit the growth of the malaria parasite.

Objective: The objective was to analyze the effect of zinc and vitamin B6 supplementation on hemoglobin level, hematocrit and erythrocyte indexs (MCV, MCH and MCHC) of anemic Plasmodium vivax malaria patients.

Methods: Double Blind Randomised Controlled Trial with pre and post test design. 30 subjects were divided into two groups: the suplementation group were given zinc $1 \times 10 \mathrm{mg} /$ day with vitamin B6 $1 \times 5 \mathrm{mg} /$ day and the control group were given a placebo for 30 days. Data analysis by paired t-test, independent t-test and Mann Whitney.

Results: There was an increase in Hb levels in the suplementation group $(p=0.0001)$, the control group $(p=0.001)$ and there was a significant difference on the increase between the two groups $(p=0.020)$. Hematocrit significant increase only in the suplementation group $(p=0.0001)$. There were no differences on erythrocyte index parameter in both groups.

Conclusion: Zinc and vitamin B6 supplementation of for 30 days increase the hemoglobin level, hematocrit and there were no effect on erythrocyte indexs of anemic Plasmodium vivax malaria patients.
\end{abstract}

Keywords: Zinc, vitamin B6, malaria vivax, haemoglobin, hematocrit and erythrocyte index.

\section{ABSTRAK}

Latar Belakang: Suplementasi seng menurunkan resiko parasitemia malaria, meningkatkan kadar serum feritin dan Hb pada penderita malaria. Seng berhubungan dengan aktivitas aminolevulinic acid dehidratase (ALAD) yaitu enzim yang mensintesis heme. Vitamin B6 bentuk piridoksal 5-fosfat (PLP) berperan dalam pembentukan asam alfa-aminolevulinat, yaitu prekursor hem dalam hemoglobin. PLP juga menghambat pertumbuhan parasit pada malaria.

Tujuan: Menganalisis pengaruh suplementasi seng dan vitamin B6 terhadap kadar hemoglobin, hematokrit dan indeks eritrosit (MCV, MCH dan MCHC) pasien malaria vivax yang anemia.

Metode: Double Blind Randomised Controlled Trial dengan pre dan post test design. Melibatkan 30 subjek yang dibagi menjadi 2 kelompok yaitu kelompok perlakuan yang diberi suplementasi seng dengan dosis 1 x10 mg/hari dan vitamin B6 1x5 mg/hari dan kelompok kontrol yang diberi plasebo selama 30 hari. Analisis data dilakukan dengan uji Paired t-test, Wilxocon, Independent t-test dan Mann whitney.

Hasil: Ada peningkatan kadar Hb pada kelompok suplementasi $(p=0.0001)$, kelompok kontrol p=0.001 dan terdapat perbedaan peningkatan antara kedua kelompok $(p=0.020)$. Peningkatan HT yang bermakna pada kelompok suplementasi saja $(p=0.0001)$. Tidak terdapat perbedaan terhadap parameter indeks eritrosit antara kedua kelompok.

Kesimpulan: Suplementasi seng dan vitamin B6 selama 30 meningkatkan kadar Hb, HT dan tidak berpengaruh terhadap indeks eritrosit pasien malaria vivax yang anemia.

Kata Kunci : Seng, vitamin B6, malaria vivax, haemoglobin, hematokrit dan indeks eritrosit.

\section{PENDAHULUAN}

Malaria masih merupakan masalah kesehatan utama di dunia dan terjadi di 107 negara, ${ }^{1}$ yang upaya pengendalian dan penurunan kasusnya merupakan

\footnotetext{
1. Dinas Kesehatan Kabupaten Batanghari Provinsi Jambi

2. Bagian Parasitologi, Fakultas Kedokteran Universitas Diponegoro, Semarang

3. Bagian Gizi Kesehatan Masyarakat, Fakultas Kesehatan Masyarakat Universitas Diponegoro, Semarang

4. Bagian Patologi Klinik, Fakultas Kedokteran Universitas Diponegoro, Semarang

5. Departemen Ilmu Gizi, Fakultas Kedokteran Universitas Diponegoro, Semarang (email korespondensi: d.nurafifah.dna@fk.undip.ac.id)
}

komitmen internasional dalam Millenium Development Goals (MDGs). ${ }^{2}$ Diperkirakan 500 juta orang terinfeksi malaria dengan angka kematian lebih dari 1 juta kasus setiap tahun. ${ }^{3}$

Annual Parasite Incidence (API) Malaria per 1.000 penduduk berisiko di Propinsi Jambi mengalami peningkatan dari 1,2 tahun 2010 menjadi 1,31 pada tahun 2012. Angka tersebut di atas API nasional $0,16{ }^{3}$ Berdasarkan data Dinas kesehatan kabupaten Batanghari diketahui API Malaria per 1000 penduduk tahun 2013 adalah 1,40 meningkat menjadi 1.79 pada tahun $2014 .^{4}$

Plasmodium/parasit yang menginfeksi pada tubuh manusia akan membelah diri dan bertambah banyak dalam hati kemudian menginfeksi sel darah 
merah. ${ }^{5}$ Infeksi parasit menyebabkan kadar hemoglobin rendah. Anemia atau penurunan kadar $\mathrm{Hb}$ pada malaria vivax terjadi pada infeksi kronis dan serangan kambuhan. ${ }^{6}$ Terjadi gangguan struktur dan fungsi eritrosit pada infeksi malaria vivax yang berulang akhirnya berpuncak pada anemia. ${ }^{7}$ Anemia pada malaria adalah anemia hemolitik, normokrom dan anemia normositik. ${ }^{8,9}$ Pemberian suplementasi tablet besi yang merupakan salah satu cara yang paling efektif untuk meningkatkan kadar hemoglobin dalam jangka waktu pendek. ${ }^{10}$ Pemberian tablet besi pada penderita malaria masih menjadi kontroversi karena mungkin memiliki efek merugikan pada infeksi plasmodium. ${ }^{11}$

Seng yang cukup, sangat penting dalam menjaga fungsi sistem kekebalan tubuh. ${ }^{12}$ Seng berhubungan dengan aktifitas aminolevulinic acid dehidratase (ALAD) yaitu enzim yang mensintesis heme. ${ }^{13}$ Suplementasi seng dapat mengurangi ketergantungan terhadap obat anti malaria dan antibiotik. ${ }^{14}$ Suplementasi seng menurunkan resiko parasitemia malaria, meningkatkan kadar serum feritin dan $\mathrm{Hb}$ pada ibu hamil malaria. ${ }^{15}$ Bentuk aktif dari vitamin B6, piridoksal 5-fosfat (PLP), selain bersifat sebagai antioksidan juga berperan dalam pembentukan asam alfa-aminolevulinat, yaitu prekursor heme dalam hemoglobin. ${ }^{17}$ Penelitian sebelumnya diketahui bahwa suplementasi seng dan vitamin $\mathrm{C}$ dapat meningkatkan kadar hemoglobin pada pasien malaria.

Penelitian ini akan menganalisis pengaruh suplementasi seng dan vitamin B6 terhadap kadar hemoglobin, hematokrit dan indeks eritrosit pada pasien malaria Plasmodium vivax yang anemia.

\section{BAHAN DAN METODE}

Penelitian ini termasuk penelitian eksperimental double blind Randomised Controlled Trial (RCT) dengan rancangan pre dan post test design. Jumlah subjek penelitian sebanyak 32 orang yang diambil secara consecutive sampling. Penelitian ini terdiri dari 2 kelompok yaitu kelompok perlakukan yang diberi intervensi suplementasi seng $10 \mathrm{mg} / \mathrm{hari}$ dan vitamin B6 $5 \mathrm{mg} /$ hari dan kelompok kontrol yang diberi plasebo selama 30 hari pemberian yang masing-masing terdiri dari 16 orang.

Subjek penelitian ini adalah pasien malaria Plasmodium vivax di Puskesmas dan RS yang merupakan lokasi penelitian pada bulan Maret hingga April 2015 yang berusia di atas 15 tahun, tidak mengalami anemia berat $(\mathrm{Hb}<8)$, tidak hamil dan tidak memiliki penyakit penyerta. Sebelum dan setelah suplementasi dilakukan pemeriksaan kadar haemoglobin, hematokrit dan indeks eritrosit untuk melihat perubahan yang terjadi dengan Automatic hematology analyzer (Mindray 2800 dan ABX Micros 60). Penelitian juga dilakukan wawancara untuk mengetahui asupan makanan menggunakan metode Food recall 24 jam selama 2 hari tidak berturut-turut yaitu pada awal dan akhir suplementasi. Pengolahan dan analisis data menggunakan program komputer dan pengolahan data asupan makanan menggunakan program Nutrisurvey.

\section{HASIL}

Subjek pada penelitian ini berjumlah 32 orang, masing-masing kelompok terdiri dari 16 orang, namun 2 orang subjek pada kelompok kontrol drop out karena komplikasi penyakit lain (1 thypus, 1 DBD) sehingga pada akhir penelitian subjek berjumlah 30 orang.

Subjek penelitian berjumlah 30 orang terdiri dari 16 orang kelompok perlakuan yang mendapatkan suplementasi seng $10 \mathrm{mg} / \mathrm{hari}$ dan vitamin B6 $5 \mathrm{mg} / \mathrm{hari}$ dan 14 orang kelompok kontrol yang mendapatkan plasebo. Data karakteristik jenis kelamin, pendidikan dan pekerjaan merupakan data kategorik. Data diolah menggunakan uji Chi-square untuk mengetahui sebaran data, dapat dilihat pada tabel 1 .

Tabel 1. Perbedaan Karakteristik Subjek Penelitian berdasarkan Jenis kelamin, Pendidikan dan Pekerjaan

\begin{tabular}{|c|c|c|c|c|c|}
\hline \multirow{3}{*}{ Variabel } & \multicolumn{4}{|c|}{ Kelompok } & \multirow{3}{*}{$\mathbf{p}$} \\
\hline & \multicolumn{2}{|c|}{$\begin{array}{c}\text { Seng + B6 } \\
(n=16)\end{array}$} & \multicolumn{2}{|c|}{ Kontrol $(n=14)$} & \\
\hline & $\mathbf{n}$ & $\%$ & $\mathbf{n}$ & $\%$ & \\
\hline \multicolumn{6}{|l|}{ Jenis Kelamin } \\
\hline Laki-laki & 8 & 50 & 7 & 50 & 1.000 \\
\hline Perempuan & 8 & 50 & 7 & 50 & \\
\hline \multicolumn{6}{|l|}{ Pendidikan } \\
\hline SMP, SMA & 10 & 27,5 & 7 & 50 & 0.491 \\
\hline Tinggi & 6 & 62,5 & 7 & 50 & \\
\hline \multicolumn{6}{|l|}{ Pekerjaan } \\
\hline Pegawai & 6 & 37,5 & 8 & 57,1 & \\
\hline Wiraswasta & 5 & 31,2 & 3 & 21,4 & 0.366 \\
\hline Lainnya & 5 & 31,2 & 3 & 21,4 & \\
\hline
\end{tabular}


Berdasarkan jenis kelamin responden dengan jenis kelamin laki-laki dan perempuan jumlahnya sama banyak yaitu 15 orang perempuan dan 15 oarng laki-laki. Jumlah pendidikan paling tinggi yaitu pendidkan lanjutan baik DII, DIII atau S1 yaitu 17 orang $56.7 \%$. jenis pekerjaan terbanyak yaitu sebagai pegawai baik pegawai negeri maupun pegawai swasta yaitu 13 orang $43.3 \%$. Berdasarkan uji statistik tidak ada perbedaan signifikan antara kedua kelompok, jenis kelamin, pendidikan dan pekerjaan $(\mathrm{p}>0.05)$.

Tabel 2. Perbedaan Subjek menurut Umur, IMT, Kadar Hb, HT dan Indeks Eritrosit

\begin{tabular}{|c|c|c|c|c|c|c|c|}
\hline \multirow{3}{*}{ Variabel } & \multicolumn{6}{|c|}{ Kelompok } & \multirow{3}{*}{$\begin{array}{c}p- \\
\text { value }\end{array}$} \\
\hline & \multicolumn{3}{|c|}{ Seng + B6 $(n=16)$} & \multicolumn{3}{|c|}{ Kontrol (n=14) } & \\
\hline & Rerata \pm SD & Min & Max & Rerata \pm SD & Min & $\operatorname{Max}$ & \\
\hline Umur (Tahun) & $34.9 \pm 8.87$ & 23 & 48 & $32.7 \pm 9.93$ & 16 & 50 & 0.539 \\
\hline $\operatorname{IMT}\left(\mathrm{Kg} / \mathrm{M}^{2}\right)$ & $24.1 \pm 1.81$ & 20.4 & 26.8 & $23.5 \pm 3,28$ & 18.9 & 28.5 & 0.566 \\
\hline $\mathrm{Hb}(\mathrm{g} / \mathrm{dl})$ & $10.2 \pm 8.87$ & 8.9 & 11.4 & $10.5 \pm 0.54$ & 9.8 & 11.6 & 0.356 \\
\hline HT $(\%)$ & $29.8 \pm 0.68$ & 25 & 33 & $30.2 \pm 2.06$ & 27.4 & 35.2 & 0.620 \\
\hline Eritrosit ( x 10 12/1) & $3.94 \pm 0.55$ & 3.13 & 5.0 & $4 \pm 0.4$ & 3.49 & 4.8 & 0.752 \\
\hline MCV (fL) & $77.3 \pm 8.01$ & 59 & 90 & $76.0 \pm 6.38$ & 64.2 & 83.4 & 0.630 \\
\hline $\mathrm{MCH}(\mathrm{pg})$ & $26.4 \pm 3.07$ & 19.1 & 32.3 & $26.3 \pm 1.94$ & 22.5 & 28.5 & 0.895 \\
\hline $\operatorname{MCHC}(\%)$ & $34.1 \pm 0.96$ & 32.3 & 36.1 & $34.7 \pm 1.12$ & 33 & 37 & 0.110 \\
\hline
\end{tabular}

Hasil penelitian ini menunjukkan umur responden rata-rata 33.9 tahun dengan umur termuda 16 tahun dan tertua 50 tahun. IMT rata-rata $23.8 \mathrm{Kg} / \mathrm{M}^{2}$ dengan IMT paling kecil $18.9 \mathrm{Kg} / \mathrm{M}^{2}$ dan terbesar 28.5
$\mathrm{Kg} / \mathrm{M}^{2}$ (tabel 2). Berdasarkan uji statistik tidak ada perbedaan signifikan antara kedua kelompok untuk karakteristik umur, IMT, $\mathrm{Hb}, \mathrm{Ht}$ dan Indeks eritrosit $(\mathrm{p}>0.05)$.

Tabel 3. Hasil Uji Beda Kadar Hb, HT dan Indeks Eritrosit antara Kedua Kelompok Setelah Suplementasi

\begin{tabular}{|c|c|c|c|c|c|c|c|}
\hline \multirow{3}{*}{ Variabel } & \multicolumn{6}{|c|}{ Kelompok } & \multirow{3}{*}{ p-value } \\
\hline & \multicolumn{3}{|c|}{ Seng + B6 $(n=16)$} & \multicolumn{3}{|c|}{ Kontrol $(n=14)$} & \\
\hline & Rerata \pm SD & Min & Max & Rerata \pm SD & Min & Max & \\
\hline $\mathrm{Hb}(\mathrm{g} / \mathrm{dl})$ & $12.8 \pm 0.94^{\mathrm{b}}$ & 11 & 13.7 & $11.3 \pm 0.82^{\mathrm{b}}$ & 10.9 & 13.1 & $0.020^{\mathrm{d}^{*}}$ \\
\hline HT (\%) & $36.74 \pm 3.1^{\mathrm{a}}$ & 31.9 & 43 & $34.58 \pm 2.16^{\mathrm{a}}$ & 31.9 & 38.1 & $0.035^{\mathrm{c}^{*}}$ \\
\hline Eritrosit ( x 10 $12 / 1)$ & $4.51 \pm 0.39^{\mathrm{a}}$ & 3.85 & 5.3 & $4.47 \pm 0.31$ & 4.07 & 5.12 & $0.649^{c}$ \\
\hline MCV (fL) & $78.5 \pm 6.72^{\mathrm{b}}$ & 74 & 95.2 & $78 \pm 3.29^{b}$ & 72.3 & 83.7 & $0.278^{\mathrm{d}}$ \\
\hline $\mathrm{MCH}(\mathrm{pg})$ & $27.7 \pm 2.58^{b}$ & 25 & 33.6 & $26.8 \pm 0.99^{\mathrm{b}}$ & 24.4 & 27.4 & $0.081^{\mathrm{d}}$ \\
\hline $\operatorname{MCHC}(\%)$ & $34.63 \pm 6.67^{\mathrm{a}}$ & 33 & 37.3 & $34.5 \pm 1.51^{\mathrm{a}}$ & 32.4 & 38.5 & $0.856^{\mathrm{c}}$ \\
\hline
\end{tabular}

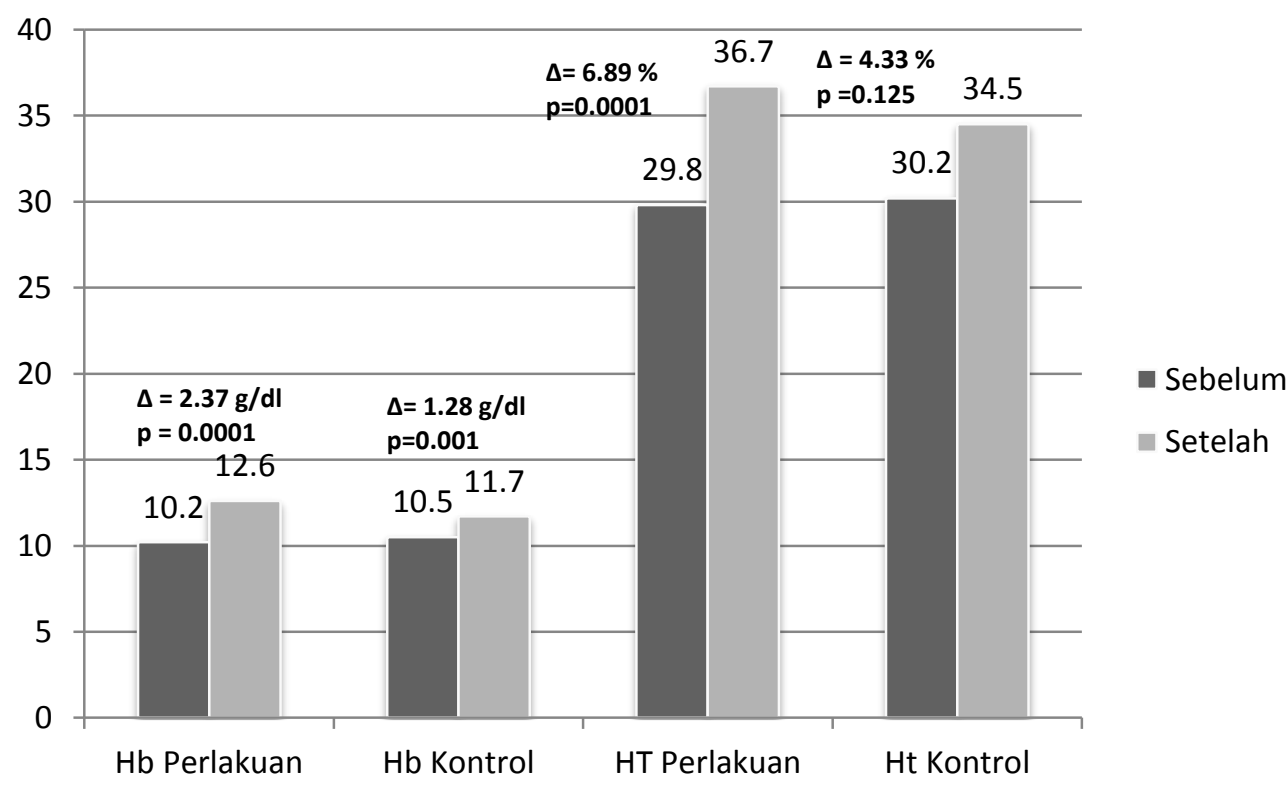

Grafik 1. Perubahan kadar Hb dan HT pada Kedua kelompok 
Hasil penelitian menunjukkan adanya peningkatan kadar Hb signifikan pada kedua kelompok. Pada kelompok suplementasi $2.37 \mathrm{~g} / \mathrm{dl}$ dan kelompok kontrol $1.28 \mathrm{~g} / \mathrm{dl}$. Hasil uji Mann- Whitney juga menunjukkan ada perbedaan antara kedua kelompok $\mathrm{p}=0.020$ (tabel 3). Hasil penelitian juga menunjukkan ada peningkatan kadar Ht pada kedua kelompok namun peningkatan yang bermakna pada kelompok suplementasi $\mathrm{p}=0.001$. Uji statistik Independent $T$-test juga menunjukkan ada perbedaan bermakna $\mathrm{Ht}$ antara kedua kelompok $\mathrm{p}=0.035$ (tabel 3).

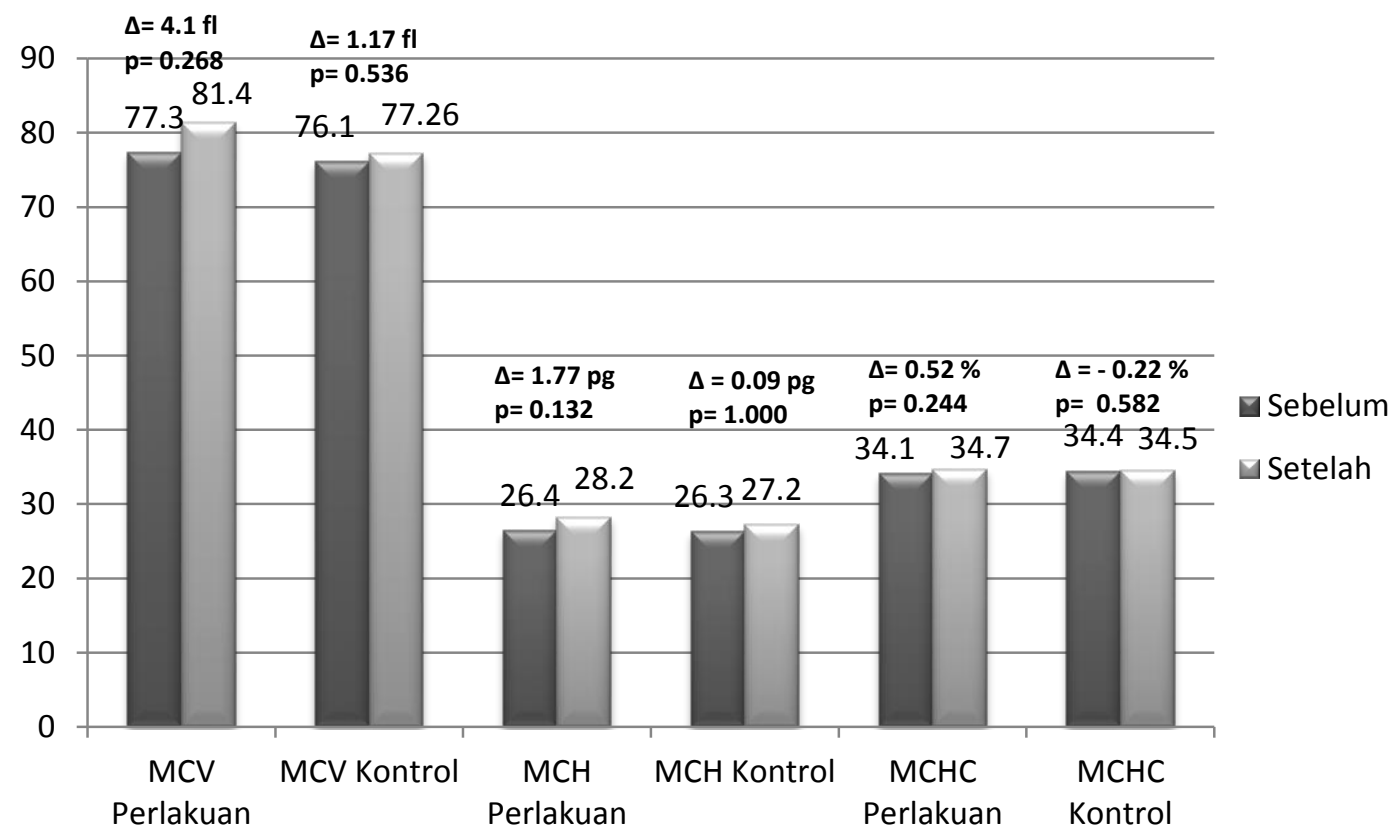

Grafik 2. Perubahan Indeks Eritrosit pada Kedua kelompok

Berdasarkan uji statistik Mann-Whitney tidak ada perbedaan signifikan indeks eritrosit MCV sebelum dan setelah pelakuan pada kedua kelompok nilai $\mathrm{p}>0.05$. Berdasarkan uji statistik Mann-Whitney nilai $\mathrm{MCH}$ pada kelompok kedua kelompok menunjukkan tidak ada perbedaan signifikan nilai $\mathrm{MCH}$ kedua kelompok tersebut $\mathrm{p}=0.081$ (tabel 3). Tidak ada perbedaan bermakna MCHC antara kedua kelompok dengan nilai $\mathrm{p}=0.856$ (tabel 3). Rerata nilai MCHC subjek $34.5 \%$ berada pada kisaran normal yaitu antara 20-35\%.

Tabel. 4 Perbedaan Asupan Zat Gizi antara Kedua Kelompok

\begin{tabular}{|c|c|c|c|c|c|c|c|}
\hline \multirow{3}{*}{ Variabel } & \multicolumn{6}{|c|}{ Kelompok } & \multirow{3}{*}{$\begin{array}{c}p- \\
\text { value }\end{array}$} \\
\hline & \multicolumn{3}{|c|}{ Seng + B6 $(n=16)$} & \multicolumn{3}{|c|}{ Kontrol $(n=14)$} & \\
\hline & Rerata \pm SD & Min & Max & Rerata \pm SD & Min & $\operatorname{Max}$ & \\
\hline Energi (kalori) & $1789 \pm 395$ & 985.9 & 2312.8 & $1938 \pm 578$ & 1030 & 3012 & 0.425 \\
\hline Protein $(\mathrm{g})$ & $56.1 \pm 13.6$ & 33 & 76 & $61.7 \pm 15.7$ & 40 & 92 & 0.307 \\
\hline Besi (mg) & $7.1 \pm 3.3$ & 3.1 & 17.8 & $7.4 \pm 2.8$ & 2.5 & 14 & 0.671 \\
\hline Seng $(\mathrm{mg})$ & $6.5 \pm 1.7$ & 3.6 & 9.8 & $6.8 \pm 2.2$ & 3.7 & 12.4 & 0.773 \\
\hline Vitamin B6 (mg) & $1.1 \pm 0.4$ & 0.5 & 2.1 & $1.2 \pm 0.5$ & 0.5 & 2.5 & 0.842 \\
\hline Vitamin C (mg) & $29.3 \pm 3.12$ & 7.6 & 135.4 & $38.9 \pm 5$ & 1.7 & 155 & 0.0001 \\
\hline
\end{tabular}

Berdasarkan hasil analisis statistik data asupan diketahui bahwa tidak ada perbedaan asupan energi, protein, besi, seng dan vitamin B6 antara kelompok suplementasi seng dan vitamin B6 dengan kelompok kontrol $\mathrm{p}>0.05$. Terdapat perbedaan pada asupan vitamin $\mathrm{C}$ antara kedua kelompok $\mathrm{p}=0.0001$, rerata asupan vitamin $\mathrm{C}$ lebih tinggi daripada kelompok suplementasi seng dan vitamin B6.

\section{PEMBAHASAN}

Adanya peningkatan kadar $\mathrm{Hb}$ pada kedua kelompok ini dapat disebabkan karena subjek mendapat pengobatan yang sama. ${ }^{18}$ Hasil penelitian ini sejalan dengan penelitian yang dilakukan oleh Lubis dan diketahui bahwa setelah parasit hilang $\mathrm{Hb}$ meningkat ketingkat yang sama. ${ }^{19}$ Namun hasil penelitian ini 
berbeda dengan penelitian Rahfiludin dan Ginandjar, karena pada penelitian tersebut peningkatan $\mathrm{Hb}$ terjadi pada kelimpok suplementasi saja. Penelitian ini juga menunjukkan tidak ada perbedaan asupan pada kedua kelompok asupan. Asupan zat gizi seperti protein, besi dan vitamin $\mathrm{C}$ juga berperan dalam pembentukan $\mathrm{Hb}^{16,17}$

Peningkatan HT lebih tinggi pada kelompok suplementasi. Penelitian ini sesuai dengan penelitian sebelumnya, yaitu terdapat perbedaan bermakna antara kelompok suplementasi seng dan kelompok kontrol. ${ }^{20}$ Peningkatan kadar HT ini seiring dengan peningkatan kadar $\mathrm{Hb}$ karena $\mathrm{HT}$ biasanya tiga kali nilai haemoglobin, kecuali bila ada bentuk dan besar eritrosit abnormal. ${ }^{21}$ Kadar haemoglobin berbanding lurus dengan kadar hematokrit, sehingga peningkatan dan penurunan hematokrit terjadi pada penyakit-penyakit yang sama. ${ }^{22}$

Data hasil penelitian menunjukkan rerata nilai MCV 78.07 fL, nilai normal MCV pada pria dan wanita antara 80-95 fL. ${ }^{23}$ Hasil ini menunjukkan kecenderungan nilai MCV subjek lebih rendah dari nilai MCV normal. MCV dibawah normal menunjukkan anemia mikrositik (ukuran rata-rata eritrosit kecil). Setelah suplementasi ada peningkatan nilai MCV menjadi normal (normositik).

Rerata $\mathrm{MCH}$ pada kedua kelompok 27.36 pg rerata ini berada pada kisaran normal. Nilai $\mathrm{MCH}$ yang normal menunjukkan normokromik (jumlah rata-rata haemoglobin normal). Hasil ini menunjukkan anemia pada malaria adalah anemia hemolitik, normokrom dan anemia normositik. ${ }^{8,9}$ Rerata nilai MCHC subjek $34.5 \%$ berada pada kisaran normal yaitu antara 20-35\%.

Beberapa zat gizi mempengaruhi sintesis hemoglobin seperti protein, besi, seng, vitamin B6 dan vitamin C. Rata-rata asupan zat gizi subjek penelitian masih dibawah AKG (angka Kecukupan Gizi) 2012. Rerata asupan energi sebesar $1858,8 \mathrm{kkal} / \mathrm{hari}$ masih dibawah kecukupan yang dianjurkan yaitu 2150-2625 $\mathrm{kkal} / \mathrm{hari}$ sesuai jenis kelamin dan umur. Rerata asupan protein 58,7 g/hari sudah sesuai dengan kecukupan yang dianjurkan yaitu 57-65 g/hari. Rerata asupan besi subjek $7.2 \mathrm{mg} /$ hari masih kurang dari kecukupan yang dianjurkan yaitu 13-26 mg/hari. Rerata asupan seng subjek $6.5 \mathrm{mg} / \mathrm{hari}$ masih dibawah kecukupan yang dianjurkan 10-13 mg/hari. Rerata asupan vitamin B6 subjek $1.1 \mathrm{mg} / \mathrm{hari}$ sudah hampir sesuai dengan kecukupan yang dianjurkan 1,2 -1,3 mg/hari. Rerata asupan vitamin C subjek $33.8 \mathrm{mg} / \mathrm{hari}$ masih dibawah kecukupan yang dianjurkan 50-75 mg/hari. Penelitian ini menemukan bahwa subjek dalam konsumsi sehariharinya kurang mengkonsumsi sayur dan buah.

\section{SIMPULAN}

Dari hasil penelitin dapat disimpulkan suplementasi seng dan vitamin B6 selama 30 hari meningkatkan kadar $\mathrm{Hb}, \mathrm{Ht}$ pasien malaria vivax yang anemia. Secara klinis ada pengaruh terhadap indeks eritrosit dari mikrositik menjadi normositik, namun secara statistik tidak ada pengaruh terhadap indeks eritrosit pasien malaria vivax yang anemia. Disarankan suplementasi seng dan vitamin B6 bisa dijadikan alternatif suplemen untuk mengatasi anemia pada malaria vivax. Perlsu penelitian lebih lanjut suplementasi seng dan B6 pada malaria untuk plasmodium yang berbeda.

\section{DAFTAR PUSTAKA}

1. RI Kementrian Kesehatan. Bersama Kita Berantas Malaria Indonesia: www.depkes.go.id; 2012. [cited 2015 Februari 17].

2. RI Pusat Data dan Informasi Kemenkes. Profil Kesehatan Indonesia 2008. Jakarta: Kementrian Kesehatan RI; 2009.

3. RI Pusat Data dan Informasi Kementrian Kesehatan. Ringkasan Eksekutif Data dan Informasi Kesehatan Provinsi Jambi Tahun 2012. Jakarta: Kementrian Kesehatan RI; 2013.

4. Kesehatan Dinas. Profil Kesehatan Kabupaten Batanghari Tahun 2013. Batanghari: Dinas Kesehatan; 2014.

5. RI Kementrian Kesehatan. Profil Kesehatan Indonesia 2010. Jakarta: Kementrian Kesehatan RI; 2011.

6. Douglas. The Anemia of Plasmodium vivax Malria. Malaria Journal. 2012 Nov; 1(135).

7. Alfonso J, Morales R. Is Anemia in Plasmodium vivax Malaria More Frequent and Severe than in Plasmodium. Am Journal of Medicine. 2006 November; 119(11).

8. Gandahusada S, Illahude HD, Pribadi W. Parasitologi Kedokteran. Jakarta: Gaya Baru; 2003.

9. UI Staf Pengajar Departemen Parasitologi, FK. Parasitologi Kedokteran. 4th ed. Inge Sutanto, Is SI, Pudji KS, Saleha S, editor. Jakarta: FKUI; 2008.

10. Mulyati Y. Perbandingan Efek Suplementasi Tablet Tambah Darah dengan dan Tanpa Vitamin C terhadap Kadar Hemoglobin Pekerja Wanita di Perusahaan Plywood Jakarta. thesis ed. Jakarta : Universitas Indonesia; 2003.

11. Pasricha SR, Drakesmith H, Black J, Hipgrave D, Biggs BA. Control of Iron Deficiency Anemia in 
Low- and Middle-Income Countries : Blood 2013; 121: $2607-17$

12. Jayant DD, Mohini MJ, Purushottam AG. Zinc in Human Nutrition and Health. Int J Med Scie and Pub Health. 2013; 2(1).

13. Kelada SN, Shelton E, Kaufman RB. dAminolevulinic Acid Dehydratease Genotype and Lead Toxicity. Am J Epid. 2001 Jan; 154:1-13.

14. Veenemas J. Effect of Preventive Supplementation with Zinc and other Micronutrients on NonMalarial Morbidity in Tanzanian Pre-School Children. Plos one. 2012 August: p. 1-9.

15. Mahama S, Jacques O, Sheley B. Effect of Joint Iron and Zinc Supplementation on Malarial Infection and Anaemia. East Af J Pub Health. 2009 April; 6(1 55-62).

16. Almatsier S. Prinsip Dasar Ilmu Gizi Jakarta: Gramedia Pustaka Utama; 2010.

17. Harijanto PN, Gajala Klinik Malaria Harijanto, editor. Jakarta: EGC; 2000.

18. Grober U. Mikronutrien Penyalarasan Metabolik, Pencegahan dan Terapi Pangabean JI, editor. Indonesia: EGC; 2013.

19. Lubis B. Dampak Suplementasi Besi dan Seng dalam Meningkatkan Eritropoiesis pada Malaria Anak yang Diberi Obat Anti Malaria di Daerah Endemis. Sari Pediatri. 2008 Juni: p.1

20. Rahfiludin MZ, Ginandjar P. The Effect of Zinc and Vitamin C Supplementation on Haemoglobin and Hematocrit Levels and Immune Response in Patients with Plasmodium Vivax Malaria. Southeast Asian J Trop Med Pun Health. 2013 September; 44.

21. Harjdjoeno H. Interpretasi Hasil Tes Laboratorium Diagnostik. III ed. Makasar: LPI UNHAS; 2007.

22. Sadikin M. Biokimia Darah Jakarta: EGC; 2002.

23. Hoffbrand AV, Moss PAH. Kapita Selekta Hematologi. 6th ed. Jakarta: EGC; 2005. 